\title{
Sensitivity of Bacterial and Fungal Plant Pathogens to the Lytic Peptides, MSI-99, Magainin II, and Cecropin B
}

\author{
Ali R. Alan and Elizabeth D. Earle \\ Department of Plant Breeding, Cornell University, Ithaca, NY 14853, U.S.A.
}

Submitted 7 November 2001. Accepted 16 March 2002.

In vitro and leaf disk assays of bacterial and fungal plant pathogens were conducted using three cationic lytic peptides, MSI-99, magainin II (MII), and cecropin B (CB). Growth of bacterial organisms was retarded or completely inhibited by low concentrations of these lytic peptides. The peptides also significantly reduced germination of fungal spores and growth of mycelia; however, higher concentrations of peptides were needed to inhibit fungal growth compared with those needed to inhibit bacteria. The relative efficacy of the peptides depended on the microorganism tested, but $\mathrm{CB}$ was the most inhibitory to the majority of the bacteria and fungi assayed. MSI-99, a synthetic derivative of MII with increased positive charge, showed equal or two- to fivefold higher antibacterial activity compared to MII in the in vitro assays. MSI-99 was also superior to MII against the oomycete, Phytophthora infestans but was slightly inferior to MII in assays with the true fungi, Penicillium digitatum and Alternaria solani. In the leaf disk assays, pretreating spores of Alternaria solani and Phytophthora infestans with the peptides at concentrations as low as $10 \mu \mathrm{g}$ per $\mathrm{ml}$ led to significant reductions in the size of early blight lesions and prevented development of any late blight lesions on tomato leaf disks. Our results from in vitro and leaf disk assays suggest that MSI-99 can be used as a transgene to generate tomato lines with enhanced resistance to bacterial and fungal diseases of this crop.

Additional keyword: antifungal.

Cationic lytic peptides have been found to play important roles in the defense systems of many organisms from insects to humans (Rao 1995). Three groups of amphipathic $\alpha$-helical peptides, cecropins (Van Hofsten et al. 1985), magainins (Zasloff 1987), and melittins (Haberman 1972), are particularly interesting due to their inhibitory effects against a broad spectrum of microbial organisms. Cecropin and magainin type peptides have very little effect on animal and plant cells at the concentrations inhibitory to bacteria and fungi while melittin is known to be cytotoxic (Blondelle and Houghten 1991; Chen et al. 1988; Nordeen et al. 1992; Powell et al. 1995).

Synthetic cecropin- and magainin-type peptides have been extensively produced and studied, thanks to their relatively simple amino acid sequences. Peptide analogues have been synthesized with substituted, deleted, or extended amino acids or by incorporating parts of two different peptides. Some of the synthetic peptides mimicking the amphipathic $\alpha$-helical structures of cecropin and magainins have been found to possess equal or increased activity, higher stability, and a broader spec-

Corresponding author: Elizabeth D. Earle; E-mail: ede3@cornell.edu. trum of antimicrobial activity than their natural counterparts while also not possessing high cytotoxicity to animal and plant cells (Andreu et al. 1992; Chen et al. 1988; Everett 1994; Jaynes et al. 1987; Maloy et al. 1990; Powell et al. 1995). It is thought that these amphipathic $\alpha$-helical peptides associate with the cytoplasmic membranes of the microbes (Christensen et al. 1988; Matsuzaki et al. 1995). It has been hypothesized that, when present at inhibitory concentrations, peptide monomers bind and insert into the lipid bilayers constituting the bacterial cell membranes, leading to disruption of the target cell membranes (Huang 2000). On the other hand, the mechanism of their antifungal activity is not well understood.

Several groups have proposed the use of antimicrobial peptides in plant protection, mainly against bacterial and fungal pathogens. Tobacco and potato plants have been engineered to express cecropins and cecropin derivatives (Allefs et al. 1995; Arce et al. 1999; Florack et al. 1995; Hightower et al. 1994; Huang et al. 1997; Jaynes et al. 1993; Osusky et al. 2000), sarcotoxin IA (Mitsuhara et al. 2000; Ohshima et al. 1999), tachyplesin I (Allefs et al. 1996), and D4E1 (Cary et al. 2000). So far no detailed study of crop plants expressing one or more magainin type peptides has been reported.

We are examining possible utilization of a synthetic magainin-type peptide, MSI-99, to enhance resistance to bacterial and fungal pathogens of tomato. Our main goals are to assess the antimicrobial potential of MSI-99 on important tomato pathogens and to select the target pathogenic microorganisms for pathogenicity assays when transgenic plants are obtained. Here, we report the results from in vitro (96-well plate) and leaf disk assays carried out to determine the effects of MSI-99 and two control peptides, magainin II (MII) and cecropin B (CB), on selected plant pathogenic bacteria and fungi.

\section{RESULTS}

In vitro antibacterial activity of lytic peptides.

The peptide treatments resulted in retardation (delay) or complete inhibition of the growth in all bacterial organisms other than Ralstonia solanacearum. The lowest peptide concentration leading to complete inhibition of growth after $96 \mathrm{~h}$ of incubation was regarded as the minimum inhibitory concentration $\left(\mathrm{MIC}_{\mathrm{L}}\right)$. Monitoring of the bacterial plates with a plate reader at $4 \mathrm{~h}$ intervals revealed that bacterial growth was sometimes retarded at concentrations lower than $\mathrm{MIC}_{\mathrm{L}}$. The lowest peptide concentration causing significant retardation of bacterial growth was designated as $\mathrm{MIC}_{\mathrm{R}}$. $\mathrm{MIC}_{\mathrm{R}}$ and $\mathrm{MIC}_{\mathrm{L}}$ were the same for some bacteria, while for others, they differed substantially (Table 1). Peptide-treated bacteria that did not differ from uninoculated Luria-Bertani (LB) medium in plate readings after $96 \mathrm{~h}$ did not grow when transferred to solid LB medium, indicating the bactericidal effects of the peptides. 
The Pseudomonad bacteria showed different responses to treatments with MSI-99 and MII but were all effectively inhibited by $\mathrm{CB}$ at a concentration of $5 \mu \mathrm{g}$ per $\mathrm{ml}$. In the assay with Pseudomonas syringae pv. tomato, $5 \mu \mathrm{g}$ of MSI-99 per ml led to $16 \mathrm{~h}$ of delay in growth. Bacterial growth was not significantly affected by MII at this concentration. An increase in the MSI-99 concentration to $10 \mu \mathrm{g}$ per ml led to complete inhibition. MII concentrations of 10 and $15 \mu \mathrm{g}$ per ml caused 12- and 32-h delays in growth, respectively. The MII concentration required for complete inhibition was $20 \mu \mathrm{g}$ per ml. Responses of Pseudomonas syringae pv. syringae to lytic peptides were very similar to Pseudomonas syringae pv. tomato (Table 1). The peptide concentrations required to cause total inhibition were also the same for both bacteria. In the assays with Pseudomonas syringae pv. tabaci, $5 \mu \mathrm{g}$ of MSI-99 or MII per ml delayed growth for 12 and $28 \mathrm{~h}$, respectively (data not shown). Increasing the concentration of these peptides to $10 \mu \mathrm{g}$ per ml led to complete inhibition.

Xanthomonas campestris pv. vesicatoria was effectively inhibited with $5 \mu \mathrm{g}$ of MSI-99 and CB peptides per ml, while the same amount of MII led to $48 \mathrm{~h}$ of delay in growth. Bacterial cells treated with $10 \mu \mathrm{g} / \mathrm{ml}$ and higher concentrations of all three peptides gave readings indistinguishable from wells containing only LB. X. campestris pv. vesicatoria was the bacterium most susceptible to these peptides in the in vitro inhibition assays.

The three lytic peptides had different effects on growth of Clavibacter michiganensis subsp. michiganensis. Treatment with $5 \mu \mathrm{g}$ of MSI-99 per ml efficiently inhibited growth. In contrast, 5 and $10 \mu \mathrm{g}$ of MII or CB per ml did not cause any change in the bacterial growth. However, $15 \mu \mathrm{g}$ of MII per ml delayed bacterial growth for $12 \mathrm{~h}$ while the same concentration of CB had no detectable effect. Complete inhibition of $\mathrm{C}$. $\mathrm{mi}$ chiganensis subsp. michiganensis was achieved by $20 \mu \mathrm{g}$ of MII and CB per ml.

Responses of Erwinia carotovora subsp. carotovora and E. carotovora subsp. chrysanthemi to peptide treatments were very similar (Table 1). Both of these bacteria were effectively inhibited by $5 \mu \mathrm{g}$ of CB per ml, while MSI-99 and MII did not cause significant change in growth at this concentration. However, a $5 \mu \mathrm{g} / \mathrm{ml}$ increase in the concentrations of MSI-99 and
MII resulted in delays of 28 and $20 \mathrm{~h}$, respectively. At 15 $\mu \mathrm{g} / \mathrm{ml}$, MSI-99 inhibited both bacteria. Increases in the MII concentrations further delayed growth of Erwinia subspp. but did not completely inhibit them. Therefore, the $\mathrm{MIC}_{\mathrm{L}}$ for $\mathrm{MII}$ could not be determined for these bacteria.

Reactions of Agrobacterium tumefaciens to lytic peptides were different from other bacteria used in the assays (Table 1). Bacterial growth was not influenced by the presence of $5 \mu \mathrm{g}$ of MSI-99 per ml. On the other hand, $10 \mu \mathrm{g}$ of this peptide per $\mathrm{ml}$ resulted in complete inhibition. Up to $25 \mu \mathrm{g}$ of $\mathrm{CB}$ per $\mathrm{ml}$ caused no significant effect, while $30 \mu \mathrm{g} / \mathrm{ml}$ led to complete lethality. Growth of this bacterium was not significantly affected by MII treatment at any concentration tested (up to $30 \mu \mathrm{g} / \mathrm{ml}$ ).

In the assays with $R$. solanacearum, growth rates of peptidetreated bacteria did not differ from those of untreated ones at the concentrations used (up to $30 \mu \mathrm{g} / \mathrm{ml}$ ). The plate readings obtained over time showed no sign of delay in the peptidetreated wells, indicating that much higher concentrations would be required to cause significant effects on bacterial growth.

\section{Antifungal activity of lytic peptides: \\ In vitro antifungal activities.}

Penicillium digitatum, Alternaria solani, and Phytophthora infestans were all affected by lytic peptide treatments, but only Penicillium digitatum was completely inhibited by all of the peptides tested (Table 1). Overall, CB caused the highest levels of inhibition of spore germination and mycelial growth. MII followed CB in inhibitory activity against true fungi. However, MII was less effective against the oomycete Phytophthora infestans than was MSI-99. Examination of peptide-treated spores by an inverted microscope, together with plate readings, revealed that the peptides delayed and reduced spore germination. Formation of abnormal germ tubes in peptide-treated Penicillium digitatum and Alternaria solani indicated effects on hyphal growth.

In vitro assays with Penicillium digitatum were performed with spores collected from 1-week-old cultures. The spore concentration used $\left(1 \times 10^{4}\right.$ spores per $100 \mu$ per well $)$ could not be distinguished from that of the potato dextrose broth (PDB) medium by the plate reader at the start of the assay. Germina-

Table 1. Sensitivity of bacterial and fungal organisms to lytic peptides

\begin{tabular}{|c|c|c|c|c|c|c|}
\hline \multirow[b]{3}{*}{ Microorganism } & \multicolumn{6}{|c|}{$\operatorname{Peptide}^{\mathrm{a}}(\boldsymbol{\mu g} / \mathrm{ml})$} \\
\hline & \multicolumn{2}{|c|}{ MSI-99 } & \multicolumn{2}{|c|}{ MII } & \multicolumn{2}{|c|}{ CB } \\
\hline & $\mathrm{MIC}_{\mathrm{R}}{ }^{\mathrm{b}}$ & $\mathrm{MIC}_{\mathrm{L}} \mathrm{c}^{\mathrm{c}}$ & $\mathrm{MIC}_{\mathrm{R}}$ & $\mathrm{MIC}_{\mathrm{L}}$ & $\mathrm{MIC}_{\mathrm{R}}$ & $\mathrm{MIC}_{\mathrm{L}}$ \\
\hline \multicolumn{7}{|l|}{ Bacteria $^{d}$} \\
\hline Pseudomonas syringae pv. tomato & 5 & 10 & 10 & 20 & 5 & 5 \\
\hline Pseudomonas syringae pv. syringae & 5 & 10 & 5 & 20 & 5 & 5 \\
\hline Pseudomonas syringae pv. tabaci & 5 & 10 & 5 & 10 & 5 & 5 \\
\hline Xanthomonas campestris pv. vesicatoria & 5 & 5 & 5 & 10 & 5 & 5 \\
\hline Clavibacter michiganensis subsp. michiganensis & 5 & 5 & 15 & 20 & 20 & 20 \\
\hline Erwinia carotovora subsp. carotovora & 10 & 15 & 10 & $>30^{\mathrm{e}}$ & 5 & 5 \\
\hline Erwinia carotovora subsp. chrysanthemi & 10 & 15 & 10 & $>30$ & 5 & 5 \\
\hline Agrobacterium tumefaciens & 10 & 10 & $>30$ & $>30$ & 25 & 25 \\
\hline Ralstonia solanacearum & $>30$ & $>30$ & $>30$ & $>30$ & $>30$ & $>30$ \\
\hline \multicolumn{7}{|l|}{ Fungi $^{\mathrm{f}}$} \\
\hline Penicillium digitatum & 20 & 60 & 20 & 60 & 20 & 60 \\
\hline Alternaria solani & 20 & $>100^{\mathrm{g}}$ & 20 & $>100$ & 20 & $>100$ \\
\hline Phytophthora infestans & 20 & $>100$ & 40 & $>100$ & 20 & 60 \\
\hline
\end{tabular}

${ }^{a}$ Numbers shown are concentrations $(\mu \mathrm{g} / \mathrm{ml})$ of peptides leading to significant retardation $\left(\mathrm{MIC}_{\mathrm{R}}\right)$ or complete inhibition $\left(\mathrm{MIC}_{\mathrm{L}}\right)$ of microbial growth.

MSI-99, magainin II (MII), and cecropin B (CB) at $5 \mu \mathrm{g}$ per ml is equivalent to approximately $2.18,2.03$, and $1.3 \mu \mathrm{M}$ solutions, respectively.

${ }^{\mathrm{b}}$ Lowest peptide concentration leading to a significant delay in bacterial and fungal growth.

${ }^{\mathrm{c}}$ Lowest peptide concentration leading to complete inhibition (lethality) of bacteria and fungi.

d Actively growing bacteria were treated with peptides at concentrations of $0,5,10,15,20,25$, and $30 \mu \mathrm{g}$ per ml.

e No significant inhibition of bacterial growth at the highest peptide concentration $(30 \mu \mathrm{g} / \mathrm{ml}) \mathrm{used}$ in the tests with bacteria.

${ }^{\mathrm{f}}$ Fungal spores were treated with peptides at concentrations of $0,20,40,60,80$, and $100 \mu \mathrm{g}$ per ml.

${ }^{\mathrm{g}}$ No complete inhibition of spore germination and mycelial growth at the highest peptide concentration $(100 \mu \mathrm{g} / \mathrm{ml}) \mathrm{used}$ in the tests with fungi. 
tion rates of untreated spores in PDB after 12, 24, and $36 \mathrm{~h}$ were 20,76 , and $87 \%$, respectively. The remaining $13 \%$ showed no change during the culture period and were considered dead. Therefore, calculations of germination rates of the peptide-treated conidia were made with the assumption that only $87 \%$ of the spores would have germinated without any peptide treatment. No sign of spore germination was present in the wells containing peptide-treated spores after $48 \mathrm{~h}$ of culture. Mycelial growth in the wells containing untreated spores could be detected by the plate reader after about $36 \mathrm{~h}$.

About $48 \mathrm{~h}$ after the start of culture, mycelia from untreated Penicillium digitatum spores covered the wells. At this time, only about $1 \%$ of the spores treated with $20 \mu \mathrm{g}$ of peptides per $\mathrm{ml}$ were in the process of germination. Mycelial growth of spores treated with $20 \mu \mathrm{g}$ of MSI-99 or MII per ml was detected by the plate reader within $72 \mathrm{~h}$, while CB-treatment led to a further delay of $12 \mathrm{~h}$. Microscopic observations (at magnification of 100 to $400 \times$ ) revealed abnormalities in the germination process and germ tube elongation of peptide-treated spores. In general, peptide treatment led to slower germ tube elongation and hyper-branching of mycelium (data not shown). By the end of microscopic observations $(120 \mathrm{~h})$, germination of treated spores never exceeded $10 \%$. Increase of the peptide concentration to $40 \mu \mathrm{g} / \mathrm{ml}$ led to total inhibition of spore germination in some wells and further delayed and reduced it in others. Complete inhibition of Penicillium digitatum spore germination was achieved by $60 \mu \mathrm{g}$ of MSI-99, MII, and CB peptides per ml. Nongerminating spores in the wells with peptides were unaltered and were assumed to be killed by the peptide treatment.

In vitro assays with Alternaria solani were performed with conidia collected from dried cultures ( 6 to 8 weeks old). The germination rate of the untreated conidia was about $77 \%$ after $48 \mathrm{~h}$ of culture in PDB. The remaining $23 \%$ of the conidia that did not show any change during this period were assumed to lack germination capacity. Therefore, $77 \%$ was considered as the maximum germination rate of conidia when calculating germination rates of the peptide-treated conidia. The concentration of conidia used ( 2 $\times 10^{3}$ spores per $100 \mu \mathrm{l}$ per well) gave a reading of approximately 0.05 at an optical density at $590 \mathrm{~nm}\left(\mathrm{OD}_{590}\right)$. This value was subtracted from the wells containing conidia in all plate readings to detect actual growth in the wells.

After the start of the assay (48 h), control wells containing untreated Alternaria solani conidia were covered with mycelia. At this time point, less than $1 \%$ conidia germination was observed in the wells treated with $20 \mu \mathrm{g}$ of MSI-99 or MII per ml. Germination was delayed another $12 \mathrm{~h}$ with $20 \mu \mathrm{g}$ of CB per $\mathrm{ml}$. Microscopic observations revealed that peptide-treated conidia differed from nontreated conidia by having unusually high numbers of short germ tubes. Abnormalities in germ tube growth were observed in all wells with peptide-treated conidia. Every time peptide concentration was increased twofold, the delay of conidia germination was increased by 12 to $36 \mathrm{~h}$. Rates of conidia germination were also significantly reduced by increased peptide concentrations. However, complete inhibition of Alternaria solani was not achieved with any of the concentrations tested. Microscopic observations of conidia treated with high concentrations of peptides over 7 days also showed that germination rates increased slightly with time (data not shown). Mycelia from peptide-treated conidia grew slowly and covered the wells by the end of 10 days. Even though not completely inhibitory, CB treatments caused longer delays in conidia germination and, therefore, slowed down the mycelial growth of Alternaria solani compared with that after treatment with MSI-99 and MII.

Reactions of Phytophthora infestans to different lytic peptides were dramatically different. Control wells turned a milky- white color within $12 \mathrm{~h}$ and readings from these wells increased threefold compared with the initial reading. Within 72 $\mathrm{h}$, readings from the control wells reached a plateau. Treating sporangia with $20 \mu \mathrm{g}$ of MSI-99 per $\mathrm{ml}$ led to lower readings than controls between 24 and $86 \mathrm{~h}$ of incubation. The same level of CB also resulted in lower readings in cultures between 24 and $132 \mathrm{~h}$ compared with control wells. However, in the later culture periods, readings from these wells exceeded those from control wells. Treating sporangia with $20 \mu \mathrm{g}$ of MII per $\mathrm{ml}$ did not cause any significant change from the plate readings from control wells. All wells containing sporangia treated with $20 \mu \mathrm{g}$ of all peptides per ml were milky-white within $12 \mathrm{~h}$ of culture, like control wells containing untreated sporangia.

Increasing the concentrations of MSI-99 and CB to $40 \mu \mathrm{g} / \mathrm{ml}$ prevented color change, so the wells were transparent and suitable for microscopic observations. About 30 to $40 \%$ of the MSI-99-treated sporangia started to germinate within $96 \mathrm{~h}$, while hyphal growth became detectable by the plate reader by $170 \mathrm{~h}$. The same amount of CB allowed sporangia germination (25 to $30 \%$ ) from the start of culture; however, hyphal growth in these wells was very slow. Treatment of sporangia with 40 $\mu \mathrm{g}$ of MII per ml led to slight reduction in the milky-white color in the wells, even though readings from these wells did not differ from initial readings for $36 \mathrm{~h}$. Readings from different wells varied significantly, indicating different levels of sporangia germination and, hence, differences in mycelial growth in these wells.

Use of $60 \mu \mathrm{g}$ and higher amounts of MSI-99 per ml resulted in further delays in germination of sporangia and growth of hyphae. Some sporangia ( 3 to $5 \%$ ) continued to germinate in these wells with 12- to 24-h delays and slowly grew to cover the wells towards the end of the culture period. Therefore, up to $100 \mu \mathrm{g}$ of MSI-99 per ml did not completely inhibit Phytophthora infestans. On the other hand, CB caused complete inhibition of germination at $60 \mu \mathrm{g} / \mathrm{ml}$ and higher concentrations. Increasing the concentrations of MII led to further reductions in the germination and mycelial growth. In the wells with $60 \mu \mathrm{g}$ of MII per ml, the color was clearer. At this concentration, sporangia germination in the wells was variable (5 to $30 \%)$. Increasing the MII concentrations to 80 and $100 \mu \mathrm{g} / \mathrm{ml}$ lowered germination (3 to $10 \%$ ) and slowed mycelial growth but did not cause complete inhibition.

\section{Effects of lytic peptides \\ on the growth of fungal pathogens on tomato leaf disks.}

Plates containing tomato leaf disks inoculated with peptidetreated conidia of Alternaria solani were observed daily. On the third day, disease symptoms were observable on both control and peptide-treated leaf disks as brownish-black lesions on the inoculated spots. As time progressed, lesions on the control disks enlarged and tissue surrounding the lesions became yellow. Lesions caused by peptide-treated conidia were significantly reduced compared with those of controls. These lesions varied from small specks to the size of an inoculation droplet. Leaf disks were scored and photographed on the seventh day after inoculation, when disease symptoms were clearly established in the control leaf disks (Fig. 1). Treating Alternaria solani conidia with $10 \mu \mathrm{g}$ of peptides per ml led to significant reductions in the infection capabilities of this pathogenic fungus. The lowest disease scores were obtained from leaf disks inoculated with MII-treated conidia (Fig. 2). The inhibitory effect of MII in disease suppression was followed by CB and MSI-99, respectively. Increases in peptide concentrations did not cause significant differences in the occurrence of disease symptoms.

Tomato leaf disks inoculated with control and peptidetreated sporangia of Phytophthora infestans were kept in a 
growth chamber set at $18^{\circ} \mathrm{C}$ with no light. Leaf disks inoculated with control sporangia started to show signs of infection but no excess hyphal growth by the end of the second day after inoculation. After three days, all control leaf disks were clearly infected at the inoculation site, whereas leaf disks inoculated with peptide-treated sporangia were not. Leaf disks were scored on the seventh day after inoculation, when severe lesions had developed in the leaf disks inoculated with untreated sporangia (Fig. 3). All leaf disks inoculated with sporangia treated with $10 \mu \mathrm{g}$ of MSI-99, MII, or CB per ml prior to inoculation were rated as 0 and showed no disease development.

\section{DISCUSSION}

Cecropin- and magainin-type peptides are thought to kill bacterial cells by their ability to disrupt membranes (Christensen et al. 1988; Matsuzaki et al. 1995). To cause lethality, these peptides should reach a lipid-dependent critical concentration (Huang 2000). However, lytic peptides are also known to cause membrane thinning and permeability below critical concentrations (Ludtke et al. 1995). Results from our in vitro antibacterial assays showed that inhibitory concentrations of lytic peptides on different bacteria varied significantly. This was not surprising, since our assays included diverse bacterial species. Variations in the components of plasma membranes may be one of the important factors causing differences in the critical concentrations for each bacteria-peptide combination (Huang

\section{Concentrations}

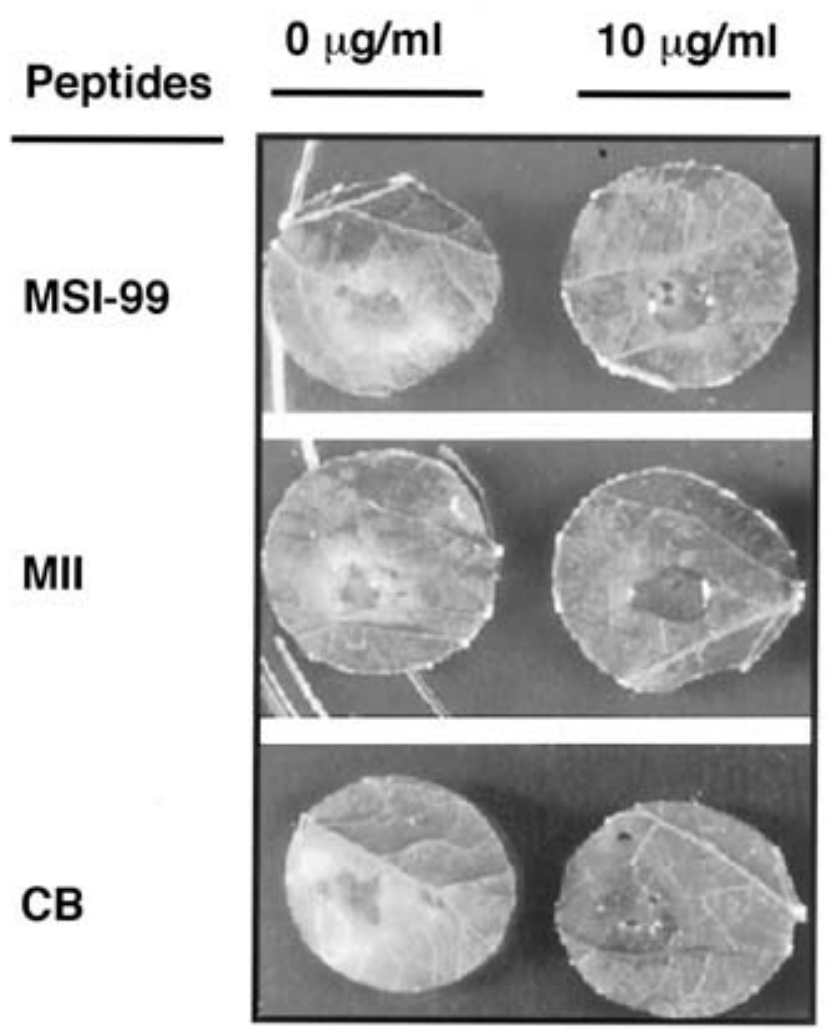

Fig. 1. Tomato leaf disks inoculated with peptide-treated conidia of $\mathrm{Al}$ ternaria solani. Conidial suspensions $(20 \mu \mathrm{l})$ that were pretreated with 0 , $10,20,30$, or $40 \mu \mathrm{g} / \mathrm{ml}$ of MSI-99, magainin II (MII), or cecropin B (CB) were placed on the adaxial side of the disks. Only the control $(0 \mu \mathrm{g} / \mathrm{ml})$ and the lowest peptide concentration $(10 \mu \mathrm{g} / \mathrm{ml})$ treatments are shown. Pretreating sporangia with as little as $10 \mu \mathrm{g}$ of peptides per ml caused substantial reductions of leaf infection by A. solani. Photographs were taken 7 days after inoculation.
2000). It should also be noted that differences in the bacterial membranes would influence rates of binding and formation of $\alpha$-helices of cationic peptides in the membranes. Therefore, bacteria may show different levels of susceptibility to cationic peptides differing in amino acid sequences and net charges.

Temporary inhibition $\left(\mathrm{MIC}_{\mathrm{R}}\right)$ of growth of some bacteria was observed at concentrations of MSI-99 and MII lower than for $\mathrm{MIC}_{\mathrm{L}}$. Once bacterial growth in the peptide-treated wells became detectable by the plate reader, growth rates of these bacteria were similar to those in the control wells. Start of growth after a period of delay might be due to insufficient levels of lytic peptides allowing some bacteria to survive and then multiply. Alternatively, inhibitory effects of magainin-type lytic peptides may be concentration-dependent. For example, at low concentrations lytic peptides may be bacteriostatic; as concentrations reach $\mathrm{MIC}_{\mathrm{L}}$, they may be bactericidal. Degradation of peptide over time may, therefore, allow multiplication of living bacteria in the wells treated with low concentrations of peptides. Our findings confirm bactericidal effects of MSI-99, MII, and $\mathrm{CB}$ at the $\mathrm{MIC}_{\mathrm{L}}$ and higher concentrations. A more informative assay of effects of different peptide concentrations on the survival and multiplication of bacteria would be to plate the treated bacteria after different periods of incubation and make colony counts. This type of assay was not carried out in our study because of high labor and time requirements.

In accordance with previous studies, magainin- and cecropin-type peptides showed lower inhibitory activity on fungi than bacteria. Our in vitro inhibition assays showed that inhibition of the most susceptible fungus (Penicillium digitatum) required 6- to 12-fold higher concentrations of peptides than the amount required to inhibit the most susceptible bacterium $(X$. campestris pv. vesicatoria). Fungal organisms are eukaryotic, and their membranes are different from bacteria. According to Matsuzaki (1995), membrane lipid composition plays an important role on the selectivity of a lytic peptide. Absence of acidic phospholipids and presence of sterols reduce susceptibility of eukaryotic cells to lytic peptides.

How cationic peptides affect fungal organisms is not well known and requires further investigation. Detailed microscopic studies of fungi treated with inhibitory concentrations of lytic peptides show distortions in plasma membranes and nuclear and mitochondrial envelopes (Kristyanne et al. 1997; Reed et al. 1997; Rioux et al. 2000). Detection of abnormalities in the cell components, such as changes in the size and shape of mitochondria, reduction in the number of ribosomes, enlargement of the vacuoles, and leakage of cytoplasmic components, indicates that lytic peptides affect the whole cellular machinery; therefore, the peptides may be fungicidal.

In vitro antifungal assays were carried out using spores from two true fungi (Penicillium digitatum and Alternaria solani) and an oomycete (Phytophthora infestans). These organisms are quite different from each other in characteristics such as spore shape and size, cell wall components, and life cycle. Therefore, plate readings alone would not provide sufficient information about their responses to lytic peptides. Accompanying microscopic observations with periodic plate readings provided valuable information on the effects of peptide treatments on the rates of spore germination and the shape and growth of the hyphae. Changes in the mycelial masses, on the other hand, were determined more reliably by the plate readings.

Pretreatment of fungal spores with low concentrations of lytic peptides caused significant reductions or prevention of disease symptoms on tomato leaf disks. Surprisingly, peptide treatments between 10 and $40 \mu \mathrm{g} / \mathrm{ml}$ led to similar results. Even though not statistically significant, treating Alternaria solani conidia with MII led to the lowest rate of disease lesion development (mostly small specks), while MSI-99 and CB 
treatments resulted in slightly larger lesions by the seventh day after the inoculations. Treating Phytophthora infestans sporangia with $10 \mu \mathrm{g}$ of any lytic peptide per ml led to complete prevention of leaf disk infection. Abnormalities in fungal germ tubes caused by peptide treatments, as detected in Alternaria solani, might have reduced the ability of the fungal germ tubes or mycelia to penetrate and grow through the leaf tissue. Ali and Reddy (2000) reported abnormalities in germ tubes and mycelia of Alternaria solani and Phytophthora infestans due to treatments with cecropin derivatives, similar to our findings. In their leaf disk assays with potato leaves, however, lesions caused by these organisms decreased as the concentrations of peptides were increased. Their study differed from ours in many ways, such as the peptides, the strains of pathogens, the concentrations of peptides and spores, and the plant species used.

According to our in vitro results, Alternaria solani and Phytophthora infestans were more significantly affected by $\mathrm{CB}$ treatment than by MII and MSI-99 treatment. However, leaf disks inoculated with CB-treated conidia had slightly higher disease scores than the ones inoculated with MII-treated conidia. MII and CB were shown to be susceptible to leaf protein extracts (Everett 1994; Mourgues et al. 1998; Owens and Heutte 1997). However, no comparative study exists about the level of degradation of MSI-99 and MII peptides in tomato leaf extracts. Activity of $\mathrm{CB}$ might be reduced faster than MII on the leaf, which in turn leads to decrease in the inhibitory pressure on conidia germination and hyphal growth.

It should also be noted that our leaf disk assays differed from in vitro assays by use of water instead of PDB or pea broth (PB) as the treatment medium and by measurement of the effects of peptide treatments on disease infection rather than on spore germination and mycelial growth. Our in vitro assays were conducted with the nutrient media that provided the most favorable conditions for the growth of the microorganisms. Therefore, a microorganism grown in different media might be affected differently by the peptide treatments.

Previously, cationic lytic peptides such as cecropins and magainins have been shown to be inhibitory to bacterial and fungal plant pathogens (Ali and Reddy 2000; Cavallarin et al. 1998; Jaynes et al. 1987; Kristyanne et al. 1997; Nordeen et al. 1992; Powell et al. 1995). Even though each study used different assays to measure inhibitory effects, it has become clear that much higher concentrations of peptides are required to cause substantial reductions on the infection ability of eukaryotic phytopathogens such as fungi and oomycetes, compared to prokaryotic phytopathogens such as phytoplasmas and bacteria. This was also apparent in our comparisons of bacteria and fungi. When we combine this information with the previous findings indicating fast degradation of the magainin- and cecropin-type lytic peptides by plant proteases, it is evident that engineering transgenic plants to produce the levels of lytic peptides required to inhibit fungal diseases would be very hard to achieve. Bacterial diseases are better targets for utilization of these lytic peptides to enhance disease resistance in crop plants, since they could be inhibited by exposure to low concentrations of peptides.

Results from our study confirmed the inhibitory activities of MII and CB on selected bacterial and fungal organisms that cause diseases in tomato and result in significant economic losses in the production of this crop. One of our main objectives was to test the antimicrobial activity of a new synthetic magainin analogue, MSI-99, for potential utilization in the genetic enhancement of tomato. Our results confirmed high and broad-spectrum antimicrobial activities of this peptide, making it desirable as a transgene in the transformation of tomato and other crops. We have obtained transgenic tobacco and tomato lines constitutively expressing a gene encoding an analog of MSI-99 (Alan 2001). The MSI-99 analog gene, containing a new Met residue on the $5^{\prime}$ end, was fused to a signal sequence enabling the peptide to be transported into the extracellular environment. Transgenic tobacco and tomato were similar to nontransformed regenerants in their growth and morphologies, and no evidence of cytotoxity due to peptide expression was observed. Homozygous tomato and tobacco lines stably expressing the MSI-99 analog were developed and tested against bacterial and fungal diseases. Results from these experiments will be published elsewhere.

\section{MATERIALS AND METHODS}

\section{Peptides.}

MSI-99 is a synthetic derivative of MII, which was originally isolated from the African clawed frog (Xenopus laevis) (Zasloff 1987). MSI-99 was generated by modifying MII as follows: the $\mathrm{His}^{7}$, $\mathrm{Gly}^{18}$, and $\mathrm{Met}^{21}$ residues were replaced with Lys, Lys, and Leu; the $\mathrm{Glu}^{19}$ residue was eliminated; and the carboxyl group $(\mathrm{COOH})$ was replaced with an amide $\left(\mathrm{NH}_{2}\right)$ (Maloy et al. 1990). MSI-99 was a gift from Sanford Scientific Inc. (Waterloo, NY, U.S.A.). MII and CB peptides were purchased from Sigma (St. Louis). The peptides were dissolved in sterile double-distilled water at a concentration of $1 \mathrm{mg} / \mathrm{ml}$ and kept at $-20^{\circ} \mathrm{C}$ until use.

In the bacterial tests, appropriate amounts of peptides were mixed with double-strength Luria-Bertani broth $(2 \times \mathrm{LB})(20 \mathrm{~g}$ of Bacto tryptone, $10 \mathrm{~g}$ of Bacto yeast extract, and $20 \mathrm{~g}$ of $\mathrm{NaCl}$ per 1) and double-distilled sterile water to obtain peptide concentrations of $0,10,20,30,40,50$, and $60 \mu \mathrm{g}$ per ml. In the fungal tests, peptides were mixed with either double-strength

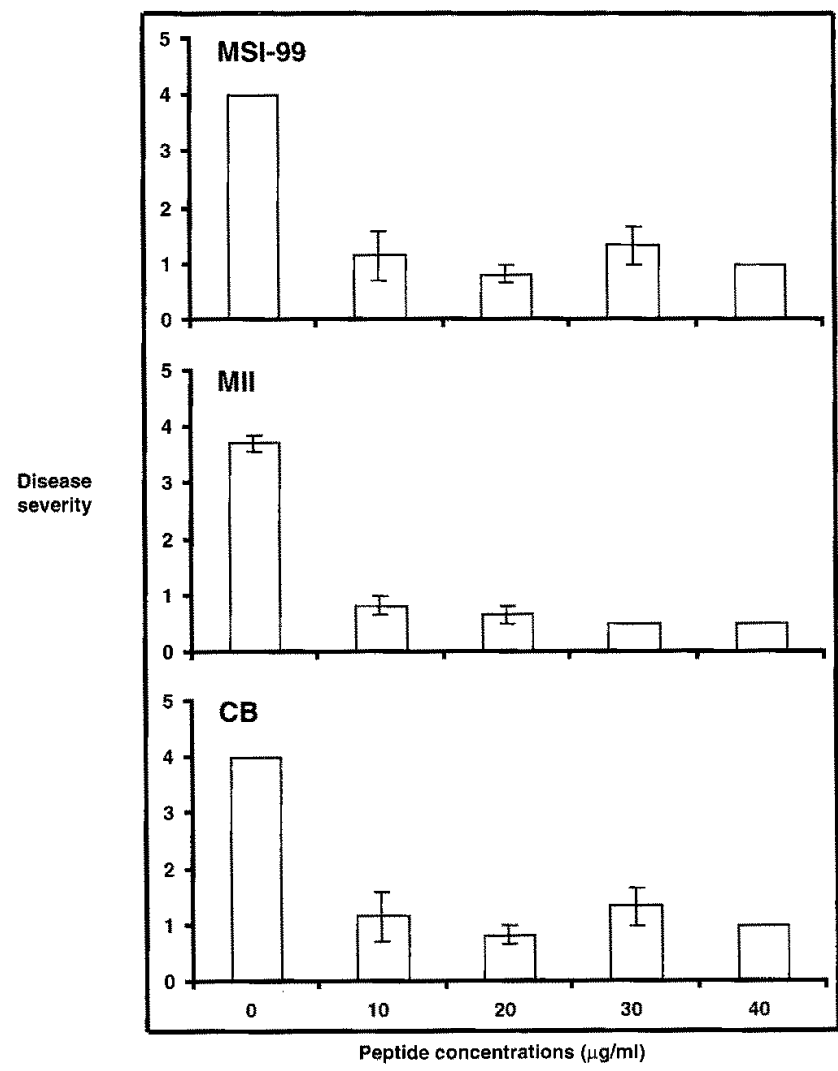

Fig. 2. Disease severity on tomato leaf disks inoculated with Alternaria solani conidia treated with MSI-99, magainin II (MII), or cecropin B (CB) (7 days after inoculation). Columns represent the mean of three replicates, and vertical bars represent standard errors of the means. 
PDB (2x PDB) (Difco, Detroit) and water or with doublestrength PB (2× PB) (filtrate from $240 \mathrm{~g}$ autoclaved frozen peas per liter) and water to obtain peptide concentrations of 0 , $40,80,120,160$, and $200 \mu \mathrm{g}$ per $\mathrm{ml}$. In the tests, $50 \mu \mathrm{l}$ of each peptide concentration was used.

\section{Microorganisms.}

A total of nine bacteria ( 8 gram negative and 1 gram positive), two fungi, and one oomycete were included in the in vitro antimicrobial assays. The following microorganisms were used: Pseudomonas syringae pv. tomato T1A (G. Martin Lab, Boyce Thompson Institute for Plant Research, Ithaca, NY, U.S.A.); Pseudomonas syringae pv. tabaci ATCC11528R, Pseudomonas syringae pv. syringae B728a, Xanthomonas campestris pv. vesicatoria, Erwinia carotovora subsp. carotovora AC4150 (A. Collmer lab, Department of Plant Pathology, Cornell University [CU], Ithaca, NY, U.S.A.); E. carotovora subsp. carotovora ATCC15713 (D. Kalb, Department of Plant Pathology, CU); Clavibacter michiganensis subs. michiganensis culture \#8 (S. Slack lab, Department of Plant Pathology, CU); Ralstonia solanacearum K-60 (S. Beer Lab, Department of Plant Pathology, CU); Agrobacterium tumefaciens LBA4404 (Gibco BRL, Rockville, MD, U.S.A.); Alternaria solani (E. Cobb, Department of Plant Breeding, CU); Penicillium digitatum culture \#07.25 (D. Kalb, Department of Plant Pathology, CU); and Phytophthora infestans isolate US940480

\section{Concentrations}

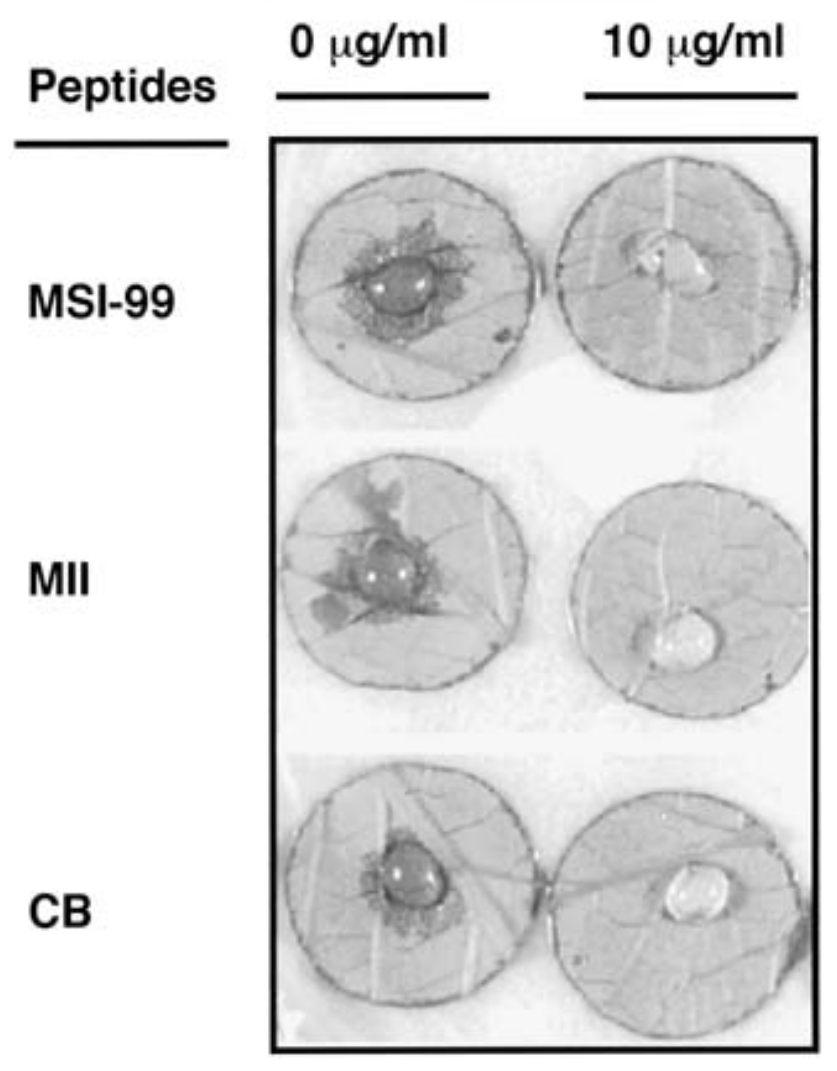

Fig. 3. Assay of tomato leaf disks inoculated with peptide-treated sporangia of Phytophthora infestans. Sporangial suspensions $(20 \mu \mathrm{l})$ that were pretreated with $0,10,20,30$, or $40 \mu \mathrm{g}$ of MSI-99, magainin II (MII), or cecropin $\mathrm{B}(\mathrm{CB})$ per $\mathrm{ml}$ were placed on the abaxial side of the disks. Only the control $(0 \mu \mathrm{g} / \mathrm{ml})$ and the lowest peptide concentration $(10$ $\mu \mathrm{g} / \mathrm{ml}$ ) treatments are shown. Pretreating sporangia with $10 \mu \mathrm{g}$ of peptides per $\mathrm{ml}$ completely inhibited leaf infection by $P$. infestans. Photographs were taken 7 days after inoculation.
(W. Fry lab, Department of Plant Pathology, CU). Leaf disk assays included Alternaria solani and Phytophthora infestans.

Bacteria were stored at $-80^{\circ} \mathrm{C}$ in $20 \%$ glycerol. The bacteria were spread over LBA medium [10 g of Bacto tryptone, $5 \mathrm{~g}$ of Bacto yeast extract, $10 \mathrm{~g}$ of $\mathrm{NaCl}$, and $15 \mathrm{~g}$ of Bacto agar per 1 (Difco)] and were incubated at $27^{\circ} \mathrm{C}$ for 2 days. Several colonies were transferred into $\mathrm{LB}$ broth and grown at $27^{\circ} \mathrm{C}$ with vigorous shaking until the mid-logarithmic-phase $\left(\mathrm{OD}_{600}=0.2\right.$ to 0.4 ). Bacterial suspensions were diluted from mid-logarithmic-phase liquid cultures to a concentration of $2 \times 10^{5} \mathrm{CFU}$ per ml.

To obtain conidia from Alternaria solani, mycelium was put on unsealed plates of V8A [16\% V8 vegetable juice (Campbell Soup Co, Camden, NJ, U.S.A.), and $3 \mathrm{~g} \mathrm{CaCO}_{2}$ and $15 \mathrm{~g}$ of Bacto agar per 1] and allowed to grow at $24^{\circ} \mathrm{C}$ in a $16 \mathrm{~h}$ light and $8 \mathrm{~h}$ dark photoperiod. The plates were allowed to dry for 6 to 8 weeks. Conidia were collected by scraping the dried medium with a sterile scalpel. The conidia were then suspended in PDB (Difco) with $0.002 \%$ Tween-20. For leaf disk infectivity assays, conidia were suspended in sterile water with $0.002 \%$ Tween-20.

Penicillium digitatum was grown on PDA (Difco) in the same conditions as Alternaria solani and subcultured to fresh PDA plates every week. The spores of this fungus were collected from 1-week-old cultures by adding $10 \mathrm{ml}$ PDB to culture plates and scraping with a sterile glass spreader.

Sporangia of Phytophthora infestans for in vitro inhibition assays were obtained from 12-day-old cultures grown at $18^{\circ} \mathrm{C}$ on PBA (PB solidified with $15 \mathrm{~g}$ of Bacto agar per 1) plates in the dark. Sporangia were harvested by adding $10 \mathrm{ml}$ PB to culture plates and scraping with a sterile glass spreader. For leaf disk infectivity assays, sporangia were harvested from previously inoculated detached leaflets of tomato. Inoculated leaflets were placed on wet Whatman \#1 paper in petri dishes and kept in the same conditions as Phytophthora cultures grown in the PBA plates. Spores were filtered through two layers of Nitex nylon fabric with $40 \mu \mathrm{m}$ mesh openings to remove the mycelial fragments. Concentrations were determined by a hemacytometer.

\section{In vitro inhibition assays.}

In vitro inhibition assays were performed in sterile flat-bottom 96-well plates (Corning, Inc., Corning, NY, U.S.A.). Although peptide concentrations and length of the assay differed in antibacterial and antifungal assays, the experiments were otherwise similar. Each peptide concentration was tested with three replications (three wells), each containing $50 \mu \mathrm{l}$ of bacterial cells or fungal spores combined with $50 \mu$ l of a peptide adjusted to a particular concentration.

\section{Antibacterial assays.}

Prior to loading to 96-well plates, $50 \mu \mathrm{l}$ of bacterial cells and $50 \mu \mathrm{l}$ of peptides were mixed in Eppendorf tubes. Thus the bacterial concentration in each well was $1 \times 10^{5} \mathrm{CFU}$ per $\mathrm{ml}$. The final peptide concentrations used in two identical antibacterial assays were $0,5,10,15,20,25$, and $30 \mu \mathrm{g} / \mathrm{ml}$. Plates were incubated at $28^{\circ} \mathrm{C}$ with continuous shaking at $200 \mathrm{rpm}$. Antibacterial effects of the peptides were determined by a plate reader (model 750; Cambridge Technology, Watertown, MA, U.S.A.) at $\mathrm{OD}_{590}$ at $4 \mathrm{~h}$ intervals for $96 \mathrm{~h}$ to determine whether some cells remain alive and start multiplying after a certain inhibitory period. The peptide concentrations leading to inhibition of bacterial growth were determined by transferring $20 \mu \mathrm{l}$ of peptide-treated bacterial cultures from wells to LBA plates at the end of $96 \mathrm{~h}$. The cultures were further incubated at $28^{\circ} \mathrm{C}$ for 2 days and observed for bacterial growth. The lowest concentration of peptide leading to retardation of bacterial growth 
$\left(\mathrm{MIC}_{\mathrm{R}}\right)$ and the lowest concentration causing complete lethality to all bacterial cells $\left(\mathrm{MIC}_{\mathrm{L}}\right)$ were determined for each bacterium-peptide combination.

\section{Antifungal assays.}

Spores and peptides were prepared in PDB, except for Phytophthora infestans, for which PB was used. In the assays with Penicillium digitatum, the spore concentrations were brought to $2 \times 10^{5}$ spores $/ \mathrm{ml}$; for the assays with Alternaria solani and Phytophthora infestans, concentrations were adjusted to $4 \times$ $10^{4}$ spores $/ \mathrm{ml}$. For the inhibition assays, $50 \mu \mathrm{l}$ of spores were mixed with $50 \mu \mathrm{l}$ of peptides in Eppendorf tubes. Hence the final concentration of spores in each well was $1 \times 10^{5}$ spores $/ \mathrm{ml}$ for Penicillium digitatum and $2 \times 10^{4}$ spores $/ \mathrm{ml}$ for Alternaria solani and Phytophthora infestans. Peptide concentrations tested in the antifungal assays were $0,20,40,60,80$, and 100 $\mu \mathrm{g} / \mathrm{ml}$. Before transfer to 96-well plates, Penicillium digitatum and Alternaria solani spores were incubated at $24^{\circ} \mathrm{C}$ for $2 \mathrm{~h}$, whereas Phytophthora infestans sporangia were incubated at $4^{\circ} \mathrm{C}$ for $2 \mathrm{~h}$ to induce zoospore release. Penicillium digitatum and Alternaria solani plates were incubated at room temperature (about $24^{\circ} \mathrm{C}$ ) under continuous light, whereas Phytophthora infestans plates were kept in a growth chamber set at $18^{\circ} \mathrm{C}$ with no light. Antifungal effects of the peptides were determined by an automated plate reader at $\mathrm{OD}_{590}$ at $12 \mathrm{~h}$ intervals for $240 \mathrm{~h}$. The wells were also observed with an inverted microscope at $12 \mathrm{~h}$ intervals for spore germination and mycelial growth. Effects of peptides on spore germination were determined by counting about 100 spores from each well at $24 \mathrm{~h}$ intervals. In order to estimate changes in the fungal mass, values from the first plate reading of each plate were subtracted from later readings. The lowest concentration of peptide leading to delay in spore germination $\left(\mathrm{MIC}_{\mathrm{R}}\right)$ and the concentration causing complete inhibition of spore germination and mycelial growth $\left(\mathrm{MIC}_{\mathrm{L}}\right)$ were determined for each fungus-peptide combination.

\section{Leaf disk infectivity assays.}

These assays were done with two important fungal pathogens of tomato, Alternaria solani and Phytophthora infestans, to observe the effects of lytic peptides on disease development on leaves. Leaf disks ( $2 \mathrm{~cm}$ in diameter) were obtained from fully developed leaves of greenhouse-grown plants of tomato (Lycopersicon esculentum cv. Mocimor). In the assays with Alternaria solani, a spore concentration of $6 \times 10^{4}$ conidia per $\mathrm{ml}$ was prepared in sterile water. The peptide concentrations were brought to $0,20,40,60$, and $80 \mu \mathrm{g} / \mathrm{ml}$ in sterile water. Conidia and peptides ( $75 \mu \mathrm{l}$ of each) were mixed in Eppendorf tubes and left in room temperature for $2 \mathrm{~h}$. Leaf disks, placed adaxial side up on plates $(15 \times 1.5 \mathrm{~cm})$ of water agar $(15 \mathrm{~g}$ of Bacto agar per 1), were inoculated with $20 \mu \mathrm{l}$ aliquots of peptide/conidia mix. Hence, the final conidia concentration was 3 $\times 10^{4}$ conidia/ml while the peptide concentrations were 0,10 , 20,30 , and $40 \mu \mathrm{g} / \mathrm{ml}$. Plates of leaf disks were kept under room conditions (approximately $24^{\circ} \mathrm{C}$ and with a $16 \mathrm{~h}$ light and $8 \mathrm{~h}$ dark cycle) and were observed daily for symptom development. Disease severity ratings were made by visual screens 7 days after inoculation, based on a 0 to 5 scale as follows: $0=$ no lesion, $1=$ occurrence of small lesions in the inoculated area, $2=$ beginning of tissue destruction in the inoculated area, $3=$ enlargement of tissue damage beyond the inoculated area, $4=$ tissue damage in large portions of the leaflet, and $5=$ total destruction of the leaflet.

In the tests with Phytophthora infestans, a spore concentration of $4 \times 10^{4}$ sporangia per $\mathrm{ml}$ was prepared. Preparation of lytic peptides and their mix with sporangia were as in the $\mathrm{Al}$ ternaria solani assay. Eppendorf tubes containing the pep- tide/sporangia mixture were incubated in the refrigerator $\left(4^{\circ} \mathrm{C}\right)$ for $2 \mathrm{~h}$ to induce zoospore release. Leaf disks, placed abaxial side up on wetted Whatman \#1 filter paper $(15 \mathrm{~cm})$ in plates, were inoculated with $20 \mu \mathrm{l}$ aliquots of peptide/sporangia mix. Plates of inoculated leaf disks were kept in a chamber with a constant $18^{\circ} \mathrm{C}$ temperature in the dark. Plates were observed daily to evaluate occurrence and development of disease symptoms. Disease severity ratings were made visually 7 days after inoculation and were based on a 0 to 5 scale similar to the early blight test. Results from the leaf disk assays were analyzed by analysis of variance. Tukey's least significant difference procedure was used to separate mean values.

\section{ACKNOWLEDGMENTS}

We gratefully acknowledge contributions of The Turkish Ministry of National Education and the Department of Plant Breeding, Cornell University, for providing financial support to A. Alan during this study. We thank A. Blowers for providing MSI-99 peptide and making valuable suggestions about the inhibition assays. Special thanks to C. Smart and H. Mayton for providing Phytophthora infestans cultures and for their assistance in the interpretation of the results obtained from assays with this organism. We thank T. Setter for letting us use the plate reader in his lab.

\section{LITERATURE CITED}

Alan, A. R. 2001. Utilization of lytic peptide and avirulence genes for developing plants with broad spectrum disease resistance. PhD. thesis, Cornell University, Ithaca, NY, U.S.A.

Ali, G. S., and Reddy, A. S. N. 2000. Inhibition of fungal and bacterial plant pathogens by synthetic peptides: In vitro growth inhibition, interaction between peptides and inhibition of disease progression. Mol. Plant-Microbe Interact. 13:847-859.

Allefs, J. J. H. M., Florack, D. E. A., Hoogendoorn, C., and Stiekema, W. J. 1995. Erwinia soft rot resistance of potato cultivars transformed with a gene construct coding for antimicrobial peptide cecropin B is not altered. Am. Potato J. 72:437-445.

Allefs, J. J. H. M., De Jong, E. R., Florack, D. E. A., Hoogendoorn, C., and Stiekema, W. J. 1996. Erwinia soft rot resistance of potato cultivars expressing antimicrobial peptide tachyplesin I. Mol. Breed. 2:97105.

Andreu, D., Ubach, J., Boman, A., Wahlin, B., Wade, D., Merrifield, R. B., and Boman, H. G. 1992. Shortened cecropin A-melittin hybrids: Significant size reduction retains potent antibiotic activity. FEBS (Fed. Eur. Biochem. Soc.) Lett. 296:190-194.

Arce, P., Moreno, M., Gutierrez, M., Gebauer, M., Dell'Orto, P., Torres, H., Acuna, I., Oliger, P., Venegas, A., Jordana, X., Kalazich, J., and Holuigue, L. 1999. Enhanced resistance to bacterial infection by Erwinia carotovora subsp. atroseptica in transgenic potato plants expressing the attacin or the cecropin SB-37 genes. Am. J. of Potato Res. 76:169-177.

Blondelle, S. E., and Houghten, R. A. 1991. Hemolytic and antimicrobial activities of twenty-four individual omission analogues of melittin. Biochemistry 30:4671-4678.

Cary, J. W., Rajasekaran, K., Jaynes, J. M., and Cleveland, T. E. 2000. Transgenic expression of a gene encoding a synthetic antimicrobial peptide results in inhibition of fungal growth in vitro and in planta. Plant Sci. 154:171-181.

Cavallarin, L., Andreu, D., and San Segundo, B. 1998. Cecropin A-derived peptides are potent inhibitors of fungal plant pathogens. Mol. Plant-Microbe Interact. 11:218-227.

Chen, H. C., Brown, J. H., Morell, J. L., and Huang, C. M. 1988. Synthetic magainin analogues with improved antimicrobial activity. FEBS (Fed. Eur. Biochem. Soc.) Lett. 236:462-466.

Christensen, B., Fink, J., Merrifield, R. B., and Mauzerall, D. 1988. Channel-forming properties of cecropins and related model compounds incorporated into planar lipid membranes. Proc. Natl. Acad. Sci. U.S.A. 85:5072-5076.

Everett, N. P. 1994. Design of antifungal peptides for agricultural applications. Pages 278-291 in: Natural and Engineered Pest Management Agents. P. A. Hedin, J. J. Menn, and R. M. Hollingworth, eds. ACS Symp. Ser. 551, American Chemical Society, Washington, D.C.

Florack, D., Allefs, S., Bollen, R., Bosch, D., Visser, B., and Stiekema, W. 1995. Expression of giant silkmoth cecropin B genes in tobacco. Transgenic Res. 4:132-141.

Habermann, E. 1972. Bee and wasp venoms. Science 177:314-322. 
Hightower, R., Baden, C., Penzes, E., and Dunsmuir, P. 1994. The expression of cecropin peptide in transgenic tobacco does not confer resistance to Pseudomonas syringae pv tabaci. Plant Cell Rep. 13:295-299.

Huang, H. W. 2000. Action of antimicrobial peptides: Two-state model. Biochemistry 39:8347-8352.

Huang, Y., Nordeen, R. O., Di, M., Owens L. D., and McBeath, J. H. 1997. Expression of an engineered cecropin gene cassette in transgenic tobacco plants confers resistance to Pseudomonas syringae pv. tabaci. Phytopathology 87:494-499.

Jaynes, J. M., Xanthopoulos, K. G., Destefano-Beltran, L., and Dods, J. H. 1987. Increasing bacterial disease resistance utilizing antibacterial genes from insects. BioEssays 6:263-270.

Jaynes, J. M., Nagpala, P., Destefano-Beltran, L., Huang, J. H., Kim, J. H., Denney, T., and Cetiner, S. 1993. Expression of a cecropin B lytic peptide analog in transgenic tobacco confers enhanced resistance to bacterial wilt caused by Pseudomonas solanacearum. Plant Sci. 89:4353.

Kristyanne, E. S., Kim, K. S., and Stewart, J. McD. 1997. Magainin 2 effects on the ultrastructure of five plant pathogens. Mycologia 89:353360 .

Ludtke, S. J., He, K., and Huang, H. 1995. Membrane thinning caused by magainin-2. Biochemistry 34:16764-16769.

Maloy, W. L., Mac Donald, D., and Brasseur, M. 1990. Design of broad spectrum antibiotic and host defense peptides based on magainin and related peptides. Pages 743-745 in: Proceedings of the 21st European Peptide Symposium. E. Giralt and D. Andreu, eds. ESCOM Science Publishers, Leiden, The Netherlands.

Matsuzaki, K., Sugishita, K., Fujii, N., and Miyajima, K. 1995. Molecular basis for membrane selectivity of antimicrobial peptide, magainin 2. Biochemistry 34:3423-3429.

Mitsuhara, I., Matsufuru, H., Ohshima, M., Kaku, H., Nakajima, Y., Murai, N., Natori, S., and Ohashi, Y. 2000. Induced expression of sarcotoxin IA enhanced host resistance against both bacterial and fungal pathogens in transgenic tobacco. Mol. Plant-Microbe Interact. 13:860868 .

Mourgues, F., Brisset, M. N., and Chevreau, E. 1998. Activity of different antibacterial peptides on Erwinia amylovora growth, and evaluation of the phytotoxity and stability of cecropins. Plant Sci. 139:83-91.
Nordeen, R. O., Sinden, S. L., Jaynes, J. M., and Owens, L. D. 1992. Activity of cecropin SB37 against protoplasts from several plant species and their bacterial pathogens. Plant Sci. 82:101-107.

Ohshima, M., Mitsuhara, I., Okamoto, M., Sawano, S., Nishiyama, K., Kaku, H., Natori, S., and Ohashi, Y. 1999. Enhanced resistance to bacterial disease of transgenic tobacco plants overexpressing sarcotoxin IA, a bactericidal peptide of insect. J. Biochem. 125:431-435.

Osusky, M., Zhou, G., Osuska, L., Hancock, R. E., Kay, W. W., and Misra, S. 2000. Transgenic plants expressing cationic peptide chimeras exhibit broad-spectrum resistance to phytopathogens. Nat. Biotechnol. 18:1162-1166.

Owens, L. D., and Heutte, T. M. 1997. A single amino acid substitution in the antimicrobial defense protein cecropin B is associated with diminished degradation by leaf intercellular fluid. Mol. Plant-Microbe Interact. 10:525-528.

Powell, W. A., Catranis, C. M., and Maynard, C. A. 1995. Synthetic antimicrobial peptide design. Mol. Plant-Microbe Interact. 8:792-794.

Rao, A. G. 1995. Antimicrobial peptides. Mol. Plant-Microbe Interact. 8:6-13.

Ratledge, C., and Wilkinson, S. G. 1988. An overview of microbial lipids. Pages 3-21 in: Microbial Lipids Vol. 1. C. Ratledge, and S. G. Wilkinson, eds. Academic Press Inc, San Diego, CA, U.S.A.

Reed, J. D., Edwards, D. L., and Gonzales, C. F. 1997. Synthetic peptide combinatorial libraries: A method for the identification of bioactive peptides against phytopathogenic fungi. Mol. Plant-Microbe Interact. 10:537-549.

Rioux, D., Jacobi, V., Simard, M., and Hamelin, R. C. 2000. Structural changes of spores of tree fungal pathogens after treatment with the designed antimicrobial peptide D2A21. Can. J. Bot. 78:462-471.

Van Hoftsen, P., Faye, I., Kockum, K., Lee, J. Y., Xanthopoulos, K. G. Boman, I. A., Boman, H. G., Engstrom, A., Andreu, D., and Merrifield, R. B. 1985. Molecular cloning, cDNA sequencing, and chemical synthesis of cecropin B from Hyalophora cecropia. Proc. Natl. Acad. Sci. U.S.A. 82:2240-2243.

Zasloff, M. 1987. Magainins, a class of antimicrobial peptides from Xenopus skin: Isolation, characterization of two active forms, and partial cDNA sequence of a precursor. Proc. Natl. Acad. Sci. U.S.A. $84: 5449-5453$ 